Izvorni članak UDK: 78.01(045) Mallarmé, S.

doi: $10.21464 /$ fit1304

Primljeno 4. 5. 2020.

\author{
Adrian Pelc \\ Universität Wien, Institut für Slawistik, Spitalgasse 2, Hof 3 (Campus), AT-1090 Wien \\ adrian.pelc@univie.ac.at
}

\title{
Mallarméov ritam: između fenomena i différance
}

\begin{abstract}
Sažetak
Pojam ritma u opusu Stephanea Mallarméa zauzima specifičnu poziciju na kojoj se prelamaju gotovo sve najizazovnije pjesnikove ideje. Slijedeći nit koju nam taj pojam pruža, u prvom se koraku utvrđuju paralele između Mallarméovih estetskih postulata i Husserlove fenomenologije. U drugom koraku, paralela Husserl - Mallarmé služi kao matrica za razumijevanje nekih temeljnih paradoksa Derridaove dekonstrukcije. Pokazat će se kako je i Derrida bio u potrazi za određenim, osebujnim ritmom. U trećem koraku bit će pokazano kako je od Mallarméa, preko Derridaove razrade, ritam (ritam pojavnosti i ritam stiha, ritam riječi i ritam bjeline) postao jednom od diskretnih, ali najradikalnijih teorijskih premisa nekih od najvažnijih filozofa postmoderne: Agambena, Kristeve, Rancièrea, Nancyja.
\end{abstract}

\section{Ključne riječi}

Stephane Mallarmé, Jacques Derrida, Edmund Husserl, stih, ritam, dekonstrukcija, fenomen, ideja

\section{Uvod}

Utjecaj Mallarméova opusa na francusku filozofiju druge polovine 20. stoljeća gotovo je očigledan: Derrida, Barthes, Kristeva, Nancy, Foucault, Rancière i Lacan oslanjaju se na Mallarméa kao na svojevrsnu krajnju, radikalnu točku modernističke poetske prakse. ${ }^{1}$ Ništa manja nije uloga što ju je za navedene filozofe igrala fenomenologija Edmunda Husserla; ona je, naročito unutar Derridaovih analiza, zauzela poziciju krajnje točke stanovite ovoga puta ne poetske, nego filozofske tradicije. U ovom radu pokušavamo, donekle nasilno, iz Mallarméova opusa izlučiti pojam ritma. Pokušat ćemo pokazati kako se u Mallarméa semantika ritma razvija na dvije različite razine te kako on unutar tog jednog pojma diskretno sažima čitav poststrukturalistički prelazak s onu stranu Husserlova fenomena, skicirajući tako putanju koju će pratiti neke od najvažnijih postmodernih estetičkih teorija.

Da bismo izveli zacrtanu demonstraciju slijedit ćemo sljedeći raspored. U prvom se koraku izlažu temeljni postulati Husserlove transcendentalne fenomenologije jer nas oni vode $u$ analizi Mallarméovih tekstova do određene točke. Zatim se, slijedeći samog Mallarméa, u drugom koraku pokušava pokazati kako na posljednjem stupnju analize Husserlova fenomenologija prestaje biti odgovarajuća interpretativna matrica za poetski predložak. U trećem koraku pokušavamo usporedno izložiti Derridaov rad na Husserlovoj fenomenologiji

Mallarméov se utjecaj, međutim, proteže i s onu stranu modernizma, prema autorima koje se već gotovo rutinski svrstava među postmoderniste. Tako Rosemary Lloyd naglašava ulogu koju je francuski pjesnik odigrao u stvaralaštvu Paula Austera te, analizirajući niz manifestacija održanih povodom stote obljetnice pjesnikove smrti, pokazuje kako njegov opus nije izgubio na vitalnosti ni na kraju još jednog stoljeća (usp. Lloyd, 2000). 
i Mallarméovim zapisima - Derridaova je rasprava, s obzirom na snagu njenih odjeka, možda presudna za navedenu problematiku. U četvrtom, zaključnom koraku, pokušavamo pokazati kakvi su i koliko dalekosežni bili ti odjeci te analiziramo na koji način određena estetska strujanja zasnovana na radikalno modernističkoj književnoj tradiciji, naizgled paradoksalno, zahtijevaju susret poetskog teksta sa stvarnošću.

\section{Prema fenomenu}

Započinjemo kratkim pregledom najvažnijih Husserlovih teza, a kao temeljni će nam tekst poslužiti djelo u kojem su one možda najjasnije artikulirane Ideje za čistu fenomenologiju i fenomenologijsku filozofiju. Polazište će nam biti Husserlov »princip svih principa«:

»Nikoja zamisliva teorija ne može nas zbuniti glede principa svih principa: da je svaki originarno dajući zor izvor opravdanosti spoznaje, da se sve što nam se originarno nudi u intuiciji (tako reći u svojoj tjelesnoj zbiljnosti) treba naprosto prihvatiti tako kako nam se daje, ali također samo u granicama u kojima nam se tako daje.« (Husserl, 2007: 52)

Koliko god se jasnim doimao ovaj princip, koliko god nam se on »originarno intuitivnim « činio, njegove su posljedice neizmjerno velike. Princip svih principa već implicira intencionalnost: svijest je za Husserla uvijek »svijest o Nečemu«; svaki doživljaj struje svijesti ima »neku vlastitu bit koja se treba intuitivno zahvatiti, neki 'sadržaj' koji se u svojoj vlastitosti može pojmiti za sebe« (Husserl, 2007: 73). Kako zahvatiti »vlastitu bit« predmeta, kako da se on prezentira »u svojoj vlastitosti« kao fenomen svijesti postaje, međutim, jedan od temeljnih i najtežih problema transcendentalne fenomenologije.

Werner Marx naglašava da Husserlova fenomenologija, postulirajući strog paralelizam između akata svijesti i njihovih predmeta, zapravo i akte i predmete koncipira kao donekle polimorfne:

$»$ Njegova (fenomenologova) tema su predmeti u onomu Kako njihove danosti kao intencionalnom korelatu prema aktima koji ih daju - svejedno radi li se o realnoj, reelnoj, idealnoj ili fiktivnoj predmetnosti.« (Marx, 2005: 47; kosopis A. P.)

Ključni je naglasak prebačen sa »što« na »kako«, »kako nam se daje«. Tih »kako«, tih načina na koje se objekt daje, ima više, a oni, prije svega, ovise o stavu (usp. Marx, 2004: 21) što ga svijest zauzima prema objektu: dok će prirodni stav imati svoje predmete, prirodoznanstveni će imati svoje, a transcendentalno fenomenološki svoje. Pritom, važno je naglasiti da će se puka stvar, ovisno o stavu koji svijest zauzima, za tu svijest pojaviti kao tri posve različita predmeta, a nijedan neće biti lažan. Husserl, stoga, piše:

»U tom smislu prirodnjak u potpunosti ima pravo slijediti 'princip': da se za svaku tvrdnju koja se odnosi na prirodne činjenice treba pitati o iskustvima koja je utemeljuju.« (Husserl, 2007: 52)

Prirodnjak zauzima određen stav koji podrazumijeva specifičnu korelaciju između svijesti i njenog objekta te dopušta da se unutar tog odnosa pojave određeni predmeti, a upravo zato što slijedi taj specifični stav, prirodnjak je u potpunosti u pravu.

Princip svih principa želi, ono što se svijesti nudi »tako reći u svojoj tjelesnoj zbiljnosti«, zahvatiti u vlastitoj biti, a takvom zahvaćanju ne odgovara svaki stav. Tako, primjerice, prirodnjak unutar svog stava jest u potpunosti u pravu, ali samo u određenoj mjeri. »Istraživač bîti« ipak se njegovim principom ne može zadovoljiti, on mora pronaći vlastiti princip koji će u neku ruku biti 
nadređen prirodnjakovom $» j e r$ zapravo netom priznati princip utemeljenja svake činjenične spoznaje putem iskustva sam već nije iskustveno uvidljiv« (Husserl, 2007: 53). Ako stavova ima više te svakom odgovara njegov predmet, tek se unutar određenog stava predmet doista pojavljuje u svojoj biti, kao fenomen.

Da bi se ono što se nudi intuiciji pojavilo u svojoj biti, potrebno je izgraditi radikalan stav koji će, naizgled paradoksalno, dovesti u pitanje i samo posto-

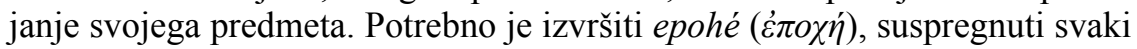
sud o intencionalnom predmetu, ali i sam prirodni stav koji uvijek pretpostavlja da predmet postoji:

»Kada to činim, što je stvar moje potpune slobode, tada, dakle, ne negiram taj 'svijet', kao kad bih bio sofist, ja ne sumnjam u opstojanje svijeta, kao kad bih bio skeptik; ali ja vršim fenome-

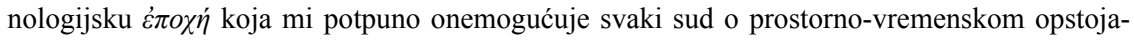
nju.« (Husserl, 2007: 68)

Epohé znači posumnjati u samu pradoksu, staviti svijet u zagrade, lišiti se čak i mogućnosti da se svijet proglasi postojećim ili nepostojećim (usp. Kidder, 1987: 232). Tek će taj fenomenološki, potpuno neutralni stav dopustiti da se

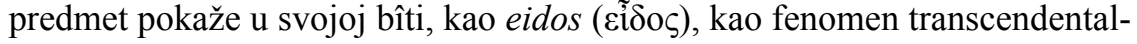
ne fenomenologije:

»Eidetska redukcija je svođenje činjeničnog stanja na njegovu bitnu strukturu s nadovezujućim opisom istoga.« (Marx, 2004: 34)

Nakon što je provedena epohé, akti svijesti i njihovi predmeti mogu biti spoznati kao bitne strukture te će kao te bitne strukture dobiti i nova imena: noesis i noema.

Husserlova fenomenologija ima za cilj da ogromnim naporom pomoću epohé dovede fenomen do prisutnosti unutar svijesti. Ona, stoga, nikako nije teorija percepcije ili reprezentacije, $u$ njoj nema ničeg spontanog ili jednostavno intuitivnog. Transcendentalna je fenomenologija, u neku ruku, razrada metode, postupka, stava koji će dovesti do pojave eidosa: fenomenologija omogućuje fenomenu da postane prezentnim. Pritom, važno je odmah naglasiti sljedeće: ako fenomenologija svoje nešto i pokazuje u njegovoj postalosti, ako i pokazuje kako se ono pojavljuje, to nešto - noesis ili noema - definirano je kao eidos, forma, bitna struktura; ono je, dakle, nakon epohé poprimilo određen oblik neovisan o genezi, neovisan o vremenu. Problem je, međutim, u tome da struja svijesti uvijek podrazumijeva vrijeme; svijest - činjenična ili transcendentalna - inherentno je vremenski fenomen (usp. Husserl, 2007: 190). Pritom, ne radi se o kozmičkom vremenu: ono je zajedno s prirodnim stavom i svijetom stavljeno u zagrade pri eidetskoj redukciji. Radi se o fenomenologijskom ili transcendentnom vremenu koje se »ne može mjeriti nikakvim položajem Sunca, nikakvim satom, nikakvim fizičkim sredstvima« (Husserl, 2007: 189). Pa ipak, fenomenologijsko vrijeme nikako nije ni individualno, subjektivno vrijeme svijesti pojedinca: ono, kao fenomen koji se pojavljuje nakon eidetske redukcije, redukcije koja dozvoljava bitne uvide, zapravo svjedoči o nemjerljivoj bîti vremena:

»Uostalom, ne treba li se recimo kazati da je način, na koji se kozmičko vrijeme očituje u fenomenologijskome, isti kao i onaj na koji se fenomenologijski prikazuju drugi, stvarni bitni momenti svijeta.« (Husserl, 2007: 189) 
Opis fenomenologijskog vremena, međutim, »stvara iznimne teškoće « (Husserl, 2007: 189). Temeljna je forma tog vremena Sada, prezent, punktualni trenutak:

»Aktualno sada nužno jest i nužno ostaje punktualno, ono je trajna forma za uvijek novu materiju.« (Husserl, 2007: 191)

Time je problem naizgled uklonjen: bitne strukture pojavljuju se uvijek unutar točke prezenta koja je i sama forma; fenomenologijsko je vrijeme tako beskonačan slijed točaka, formi unutar kojih se pojavljuju druge forme; kad se vrijeme sagleda u svojoj bîti, ono gotovo da prestaje biti vrijeme te postaje niz točaka. Ipak, Husserl sustavno inzistira na vremenskoj struji, toku koji ne dopušta da ga se konceptualizira kao niz punktualnih sada-formi. Zato je točku prezenta potrebno gotovo »rastegnuti«: svaki prezentni doživljaj obuhvaća retenciju, "primarno sjećanje « te protenciju, neposredno predviđanje (usp. Husserl, 2007: 170), određeno »netom bilo« i »buduće nadolazeće« (Husserl, 2007: 170). Samo se Sada, međutim, time pojavljuje kao konstrukt, svoj čisti, punktualni identitet duguje ritmu retencija i protencija:

»Stalni tijek retencija i protencija posreduje putem jedne također tekuće faze originarnosti, u kojem živo 'Sada' doživljaja biva posviješćeno nasuprot njegovom 'Prije' i 'Kasnije'. (Husserl, 2007: 174)

Vrijeme je, s jedne strane, definirano kao točka, čisto sada; s druge je strane vrijeme definirano kao struja unutar koje tek ritam dolazećeg i netom prošlog stvara formu prezenta: prezent kao fenomen, kao bitna struktura pojavljuje se tek kao rezultat tog neuhvatljivog ritma. $\mathrm{S}$ jedne strane, stoji struktura prezenta, s druge strane, geneza iz ritma protencija i retencija. Zapravo se problem sličan onome koji se ocrtao pri analizi fenomenološkog vremena može primijetiti već i unutar Husserlova rada na intencionalnosti. S jedne je strane svijest uvijek svijest o nečemu, ona uvijek ovisi o načinu na koji se unutar određenog stava pojavljuje njen predmet; parafrazirajući još jednom Wernera Marxa, ona smisao pokazuje u njegovoj postalosti i time je kritična prema zatvaranju u metafizički sistem. S druge je strane predmet transcendentalne svijesti uvijek bît, apsolutno opći eidos predmeta, neovisan o svakoj postalosti. Uz to Husserl zapravo krhku ravnotežu između cogitatio i cogitationes ne može zadržati; ako je svijest uvijek intencionalna, ona je ipak svom predmetu i nadređena. Citirajmo nekoliko ulomaka:

»Teza svijeta, koji je jedan 'slučajni' svijet, stoji dakle nasuprot tezi mog čistog Ja i jastvenog života koja je 'nužna', naprosto nedvojbena.« (Husserl, 2007: 102)

»Dakle, nikoji realni bitak, nikoji bitak koji se svjesno prikazuje i pokazuje putem pojava, nije nužan za bitak same svijesti.« (Husserl, 2007: 109)

»... svijest treba biti ono što je apsolutno, u kojemu se konstituira sve transcendentno, dakle, naposljetku, i čitav psihofizički svijet.« (Husserl, 2007: 121)

Husserlovu fenomenologiju uvijek prati taj dvostruki pomak, gotovo kontrapunkt: $\mathrm{s}$ jedne strane, stoje bitne strukture, čisto Ja i punktualni prezent, s druge, beskonačni ritam struje retencija i protencija, paralelizma noesisa i noeme, postanak smisla unutar stava. Pokušat ćemo pokazati kako Mallarmé, razvijajući teorije poetskog ritma, uspostavlja sličnu, aporetičnu logiku: književni tekst pomoću ritma, s jedne strane, dovodi eidos do prisutnosti, on zamjenjuje epohé dopuštajući bitnim strukturama da postanu prezentne; s druge strane, on uvijek svjedoči o genezi tog eidosa, genezi koja se po sebi nikad ne može pojaviti. 


\section{Mallarméov ritam}

Prije nego što pređemo na interpretaciju Mallarméovih tekstova, analizu je potrebno prekinuti kratkom metodološkom napomenom. Gotovo svaki se komentator Mallarméova opusa nužno suočava s onime što se još za života pisca nazivalo njegovom opskurnošću, hermetičnošću, nerazumljivošću. Pred ovim se problemom može zauzeti dva oprečna stava. S jedne se strane može jednostavno odustati od tumačenja; Charles Chassé u predgovoru svoje studije Les clefs de Mallarmé navodi kako već pjesnikovi suvremenici nisu smatrali da njegove »hermetične « pjesme imaju objektivno značenje, »vjerovali su da ta djela imaju jedan smisao ujutro, drugi u podne, a treći po noći« (Chassé, 1954: 9). Iz ove je perspektive tumačenje Mallarméova opusa ne samo nemoguće nego i nepoželjno, kao da se približava svojevrsnom svetogrđu. S druge se strane može zauzeti upravo suprotan stav, može se poći od premise da teški stil, sintaktičke inverzije i elipse, jednom kada se pronađe »ključ« njihova čitanja, skrivaju jasno odrediv, ponekad čak i banalan sadržaj; tu će premisu dosljedno slijediti prethodno citirana studija.

Možda je, međutim, korisno vratiti se samom Mallarméu, pasusu iz njegova razgovora s Julesom Huretom u kojem, suočen upravo sa zamjerkom o opskurnosti, on gotovo jasno definira svoju poetiku:

»Imenovati predmet, to znači ukloniti tri četvrtine užitka u pjesmi, užitka koji se sastoji u tome da se malo po malo odgonetava: nagovijestiti ga, eto sna. To je savršena uporaba onog misterija koji stvara simbol: prizivati malo po malo neki predmet kako bi se pokazalo stanovito stanje duše, ili obratno, izabrati predmet i iz njega izvući stanje duše, serijom dešifriranja. « (Mallarmé, 1970: 869) $)^{2}$

Čini se da je Mallarmé na strani onih koji se upuštaju u tumačenje: serija dešifriranja trebala bi, već prema logici te operacije, u konačnici dovesti do označenog predmeta ili stanja duše. Samo nekoliko rečenica kasnije, međutim, Mallarmé će ustvrditi:

»U poeziji uvijek mora postojati enigma, to je svrha književnosti.« (Mallarmé, 1970: 869)

Tako se pasus o opskurnosti završava radikalnom afirmacijom enigme, ne njenog tumačenja. Kada Mallarmé navodi da u književnosti ne smije biti »ničega osim aluzije«, više je nego upitno može li se još uvijek doprijeti do predmeta na koji se aludira. Suočeni smo, s jedne strane, sa stalnim zahtjevom za tumačenjem, dešifriranjem, dok je, $s$ druge strane, takav pokušaj u određenoj mjeri unaprijed osuđen na neuspjeh; u Mallarméovim se tekstovima ne radi ni o potpuno proizvoljnom smislu koji se mijenja kroz dan, ni o jednostavnom ključu koji bi nam otkrio njihovo značenje.

Da bismo zaključili ovu uvodnu, metodološku napomenu, navest ćemo i rad Jacquesa Derridaa koji je, u neku ruku, zaoštrio skicirani problem. Polemizirajući s tematskom kritikom (sugovornik mu je J. P. Richard i njegova studija L'univers imaginaire de Mallarmé), Derrida navodi da su lateralni odnosi među Mallarméovim motivima potencijalno beskonačni. Ako bi se, primjerice, htjelo analizirati mallarméovsku lepezu, trebalo bi uzeti u obzir sva $\gg$ krila, nabore, pera, stranice, šuštanja, letove, plesačice, jedra itd.« (Derrida, 1972: 283). Čak i kada bi se ovu seriju moglo zatvoriti, prema Derridaovu bi tuma-

2

Svi su prijevodi Mallarméovih citata autorovi. Temeljni je princip bio da se pokuša prevoditi što doslovnije. Zbog težine predloška koji je često strukturiran upravo tako da onemogući precizan prijevod, moguće su greške i odstupanja o kojima će čitatelj sam donijeti sud. 
čenju i dalje ostao stanovit višak koji, strogo uzevši, ne pripada polju smisla, nego označava pokret samog teksta, teksta kao rastvaranja i zatvaranja lepeze:

»Bjelina je stoga ukupnost polisemične serije, makar ona bila i beskonačna, plus spacionirani procijep [entr'ouverture espacée], lepeza koja od njega formira tekst. [...] Bjelina je polisemični totalitet bjelina plus mjesto pisanja.« (Derrida, 1972: 284)

Čak i kada bi interpretativni proces mogao zahvatiti »polisemični totalitet«, pokret samog teksta i dalje bi mu izmicao.

Svaki pokušaj da se iz Mallarméova opusa izolira i tumači jedan motiv ili jednu riječ osuđen je na to da bude donekle nepravedan prema tom opusu i toj riječi, osuđen je na to da u nekoj mjeri bude neprecizan, čak i pogrešan. Imajući ova ograničenja u vidu, možemo se vratiti svojem interpretativnom pitanju: koju ulogu u Mallarméovu opusu igra motiv ritma, a koje su paralele između tog ritma $i$ transcendentalne fenomenologije? A to će nas pitanje, na koje očito nećemo moći dati iscrpan odgovor, određenim lateralnim pomakom voditi do sljedećeg pitanja na koje će se, kao što ćemo vidjeti, moći dati mnogo jasniji odgovor: na koji način Mallarméov ritam okuplja neka od radikalnih estetskih promišljanja 20. (pa i 21.) stoljeća, kako se oko njega formira određen estetski program koji možda, strogo uzevši, više nije Malarméov, ali kojem je pjesnikov opus služio kao presudan oslonac? Mallarméov ritam služit će nam kao svojevrsna nit vodilja pomoću koje ćemo više rasvjetljavati teorijske postulate, nego njega samog, on će predstavljati točku okupljanja teza koje diskretno, ali radikalno prevrednuju neke od najraširenijih postulata o modernoj umjetnosti.

Analizu ćemo započeti slijedeći Mallarméa, istaknut ćemo neka (nikako sva) mjesta na kojima se unutar njegova opusa pojavljuje motiv ritma te ćemo na taj način pokušati ocrtati konture problema koji nas zanima.

Ritam je za Mallarméa, prije svega, ritam stiha. Tako on, ponovno prilično jasno, nastupajući protiv dominacije aleksandrinca kao tradicionalnog francuskog metričkog obrasca, piše:

»Nije li vrlo abnormalno to da, otvarajući bilo koju knjigu poezije, možemo biti sigurni da ćemo u njoj naći, s kraja na kraj, uniformne i uobičajene ritmove tamo gdje tvrdimo, upravo suprotno, da se zanimamo za esencijalnu raznolikost ljudskih osjećaja?« (Mallarmé, 1970: 867)

Problem je jasan, gotovo banalan: uniforman versifikacijski sistem aleksandrinca - ritam koji nalazimo u svakoj knjizi poezije - čini svojevrsno nasilje nad individualnim osjećajima; ako pjesnik želi reprezentirati jedinstvene osjećaje, pisati osobnu poeziju, potreban mu je slobodan stih kojim će ih izraziti. Odmah se, međutim, pojavljuje nekoliko problema. Prvo se možemo zapitati koji su to osjećaji kojima je potreban idiosinkratski poetski ritam, a to će se pitanje ponovno granati u dva smjera. Za početak, možemo citirati kraj jednog drugog pasusa koji se također bavi potrebom za time da se afirmira slobodan stih. Mallarméov argument, međutim, ovoga puta završava tvrdnjom da je slobodan stih nužan »jer je svaka duša ritmičan čvor « (Mallarmé, 1970: 644). Različiti ritmovi služe izražavanju različitih osjećaja, koji su i sami ritmovi. Tradicionalno rečeno, ritam je iz područja forme prešao i na područje sadržaja. Ako sada prijeđemo na najslavniji Mallarméov tekst o problematici vers libre, »Krizu stiha«, zapadamo u daljnje probleme:

»Čisto djelo implicira izričajni nestanak pjesnika, koji inicijativu prepušta riječima, srazom njihovih pokrenutih nejednakosti; one se osvjetljavaju recipročnim odrazima kao nestvarna putanja vatre po draguljima, zamjenjujući primjetno disanje starog lirskog daha ili osobno, entuzijastično usmjerenje rečenice.« (Mallarmé, 1970: 366) 
Izgleda da s aleksandrincem, "primjetnim disanjem starog lirskog daha«, nestaje i pjesnik, pojedinac, onaj u ime čijih je osjećaja, koji su bili ritmovi, u poeziju trebalo uvesti ritmičku slobodu.

Kad riječi preuzmu inicijativu, čini se da i sama razlika između stiha i proznog diskursa (osim, diskursa univerzalne reportaže) nestaje:

»Stil, versifikacija, ako ima ritma, i zato sva proza sjajnih pisaca, izvučena iz uobičajene proizvoljnosti, vrijedi kao prekinut stih.« (Mallarmé, 1970: 644)

"Stih je svugdje u jeziku, svugdje gdje ima ritma, osim u oglasima i na četvrtoj stranici novina.« (Mallarmé, 1970: 867)

Ritam je, dakle, od kodificiranog versifikacijskog sistema, preko ljudske duše, postao specifičan modalitet jezika koji više nije svodiv na stih u uobičajenom smislu te riječi. Sljedeće je pitanje o tome kakav bi bio taj novi modalitet. I opet nam odgovor nudi »Kriza stiha«: Mallarmé u njoj iznosi svoj slavni argument o tome da su jezici nesavršeni jer ih je više, jer nijedan svoje objekte ne imenuje na apsolutan način. Izlaz iz te situacije jest stih (u svom punom značenju ritmičnog jezika), koji »filozofski nadoknađuje nedostatak jezika, taj vrhunski dodatak « (Mallarmé, 1970: 364). Naravno, ovaj vrhunski dodatak najčešće se tumači kao Mallarméov kratilovski zahtjev za time da se stvori motivirana veza između označitelja i označenog (usp. Ouellet, 1989). Mallarmé neposredno prije citiranog fragmenta daje primjer nesavršenosti jezika: jour (fr. dan) zvuči neusporedivo tamnije u odnosu na nuit (hr. noć). Stih, ritmični jezik, takva bi nepodudaranja trebao ispraviti uvodeći svojevrsnu formalnu nadgradnju.

Ovaj kratilovski zahtjev, međutim, treba slijediti do njegovih krajnjih konzekvenci. Ako bi nastupilo potpuno podudaranje između označitelja i označenog, ako bi nastao jedan savršen jezik, onda bi pluralnost bila ukinuta, ostao bi jedan jedini tekst kao utjelovljena istina:

»Sve knjige sadrže spoj konačnog broja ponovljenih fraza (redit): čak i kad bi postojala samo jedna - na svijetu, njegov zakon - biblija kako je lažno prikazuju narodi. Razlika, od jednog djela do drugog, nudeći toliko predloženih lekcija unutar ogromnog natjecanja za istiniti tekst, među dobima koja nazivamo civiliziranima ili - pismenima.« (Mallarmé, 1970: 367; kosopis A. P.)

Pokret ritmičnog jezika zamišljen je, dakle, kao svojevrsno asimptotično približavanje jednom, istinitom, apsolutnom tekstu. Kad se taj ideal dostigne, predmet će potpuno odgovarati svom imenu:

»Kažem: cvijet! i, izvan zaborava u koji moj glas ne zatočuje nijedan obris, kao nešto drugačije od poznate čaške, muzički se uzdiže, ideja sama i ljupka, odsutna iz svih buketa.« (Mallarmé, 1970: 368)

Ono što odgovara svom imenu nije, međutim, nijedan stvarni referent nego ideja - eidos (Eĩos $)$ cvijeta, sama i ljupka. Baudelaire, jedan od Mallarméovih velikih uzora, nešto je ranije napisao:

»Ritam je nužan kako bi se razvilo ideju ljepote koja je najplemenitiji cilj pjesme.« (Baudelaire, 1976: 329)

U ovoj konstelaciji, ritmični jezik preko ideje cvijeta ili bilo kojeg drugog predmeta cilja na ideju ljepote, on treba dovesti do prisutnosti eidos predmeta, a time i eidos same ljepote.

Nije teško primijetiti da ritam u svom novom opsegu za Mallarméa vrši ulogu sličnu ulozi fenomenološke redukcije. Subjekt-pjesnik nestaje kao pojedinac; 
taj nestanak, međutim, mora u neku ruku biti aktivan: Mallarméova Knjiga nema potpisnika, ali je istovremeno djelo genija (usp. Mallarmé, 1970: 346). Genij time postaje onaj koji je sposoban aktivno ukinuti vlastitu, pojedinačnu subjektivnost, prepustiti se ritmu koji do prisutnosti dovodi eidos. Gotovo bismo mogli reći da genij mora biti sposoban promijeniti stav. Epohé - stavljanje svijeta u zagrade - podrazumijeva da individualna psihologija kao dio prirodnog svijeta i prirodnog stava i sama mora nestati; subjekt transcendentalne redukcije ne oslanja se na osobno, individualno iskustvo unutar prirodnog stava, on do fenomena dopire tek susprežući svaki sud, uzdižući se do polja inherentno ne-psihološke, transcendentalne svijesti. U neku bi ruku Mallarméov ritam slijedio istu putanju: on je na prvoj razini bio ritam pjesme, jednostavan element versifikacije te izraza raznolikih osjećaja pojedinca; na drugoj je razini on, međutim, bio sredstvo kojim pojedinac (taj ritmični čvor) ukida vlastiti izraz, okreće se od pojedinačnih osjećaja koji ostaju vezani uz prirodni stav te omogućuje da se pojave tri fenomena na tri razine: eidos jezika, eidos predmeta (cvijeta) te eidos ljepote.

Genijalnost se pomoću ritma izražava kao svojevrsno krčenje puta eidosu, ona ne reprezentira eidos, nego mu omogućuje da se pojavi: kad subjekt raznolikih osjećaja prestane koristiti jezik kao sredstvo izraza te se prebaci na razinu subjekta-ritmičnog čvora, on svom jeziku omogućuje da se i sam pojavi kao ritam. Držeći se Husserlova paralelizma, mogli bismo taj odnos opisati na sljedeći način: kad noesis zadobije strukturu ritmičnog čvora, odgovarajuća noema postaje ritmičan jezik. Kako se taj jezik, međutim, sad pokazuje kao bitna struktura, kako on od sredstva izraza postaje eidos jezika, on postaje apsolutno istinit te ne reprezentira predmete nego ih do prisutnosti dovodi kao fenomene; oni pak, kao forme, do prisutnosti dovode samu formu forme, eidos ljepote.

Čvrstu vezu između imenovanja i predmeta koji se sad pojavljuju kao fenomeni, Mallarmé eksplicitno ističe:

»Stih, koji od više glasova iznova stvara totalnu riječ, novu, stranu jeziku, kao inkantaciju, dovršava tu izolaciju govora: negirajući, suverenim potezom, slučaj koji ostaje u pojmovima, unatoč vještini njihovog izmjeničnog kaljenja u smisao i u zvučnost, izaziva u vama iznenađenje što nikad niste čuli tako običan fragment govora, dok se reminiscencija na imenovani predmet kupa u novoj atmosferi.« (Mallarmé, 1970: 368; kosopis A. P.)

Čak i »tako običan fragment govora« sada se pojavljuje kao bitan fenomen jer je »suverenim potezom« iz pojmova izbrisan slučaj; poetski jezik, dakle, nije nužno kompleksan, on prije označava onu operaciju kojom se jezik, bilo koja jezična formulacija, prestaje manifestirati kao stvar u svijetu i počinje manifestirati kao fenomen - on inducira promjenu stava prema jeziku. A ta promjena, takoreći automatizmom, implicira i promjenu stava prema predmetu: reminiscencija na imenovani predmet kupa se u novoj atmosferi.

Iz te perspektive, Mallarméov bi se ritam moglo smatrati svojevrsnim sredstvom očuđenja: ritam kao epohé jednim potezom nudi nov pogled na jezik i na predmet, oni se pojavljuju očišćeni svih naslaga dokse koje su se na njima kroz vrijeme nataložili. U tom bi smislu Mallarméova estetika ritma zapravo bila bliska romantičarskoj estetici Arthura Schopenhauera koji je tražio da umjetnost reprezentira isključivo eidos, bitnu formu (usp. Schopenhauer, 2012: 17), ali i teorijama koje su na planu jezika kasnije razvijali ruski formalisti tražeći uskrsnuće riječi. Ritam koji je mijenjao razine - od ritma stiha preko ritma duše do ritma umjetničkog jezika - u konačnici se smiruje $u$ 
samoprisutnosti jezika i ideje te superiornom načinu gledanja; kao što je to David Evans formulirao:

»Ritmična priroda ljudske duše podržava poetsku iluziju, učvršćuje nužnu superiornost stiha čiji metar istovremeno zadovoljava urođenu ljudsku potrebu i pokazuje prema idealnom Ritmu unutar blještavog transcendentalnog predjela.« (Evans, 2004: 220)

Pa ipak, treba imati na umu nekoliko elemenata koji će remetiti ovu urednu shemu unoseći u nju nemir, udaljavajući je od estetskih postulata na koje smo navikli. Kao prvo, ovdje se, kao i unutar Husserlove fenomenologije, ne radi o teoriji reprezentacije: jezik ne predstavlja ideju istinito, on, jednom kada postane savršen, jest ideja. Mallarméov usklik »Stih, inkantacijski dah (trait incantatoire)! (Mallarmé, 1970: 400) dobiva u ovom kontekstu sasvim jasan smisao: jezik poezije ne prikazuje; dolazeći u prisutnost samoponištenjem subjekta, on dovodi fenomen do prisutnosti - »Kažem cvijet! I iz zaborava...« Odmah se, međutim, pojavljuje nov problem: ako su objekt i njegovo ime jedno te isto, gdje je aluzija, sugestija, enigma koja je svrha književnosti? Ovdje se, kako bi spasio književnost, pojavljuje nov ritam, ritam koji u beskraj dijeli inkantacijski jezik - koji ne označava, nego dovodi do prisutnosti - od njegove ideje:

»Sve postaje neizvjesnost, fragmentaran raspored, izmjeničan i nasuprotan, težeći totalnom ritmu, koji bi bio ušutkana pjesma, u bjelinama.« (Mallarmé, 1970: 367; kosopis A.P.)

To nije više ritam riječi savršenog jezika, nego ritam bjelina koje ih dijele, totalni ritam tišine, $» k a o$ let skupljen, ali spreman da se raširi, zahvat svijanja ili ritam, početni uzrok toga da zatvoren list sadrži tajnu, tišina na njemu ostaje, dragocjena, i evocirajući ${ }^{3}$ znakovi slijede, za duh, za sve literarno uništen « (Mallarmé, 1970: 379; kosopis A. P.).

Čitav je problem možda sadržan u inkantaciji: jezik, s jedne strane, napušta svoju reprezentativnu, referencijalnu funkciju; on zaziva, ali, s druge strane, zazvana ideja još nije došla do prisutnosti: poetski jezik (premda se ovdje zapravo radi o općoj estetici koja u najmanju ruku uključuje ples, kazalište i muziku) više ne znači, a još nije postao tijelo istine. Ako je Derrida dva velika (i jedina) modusa promišljanja istine na Zapadu definirao kao mimesis $(\mu$ í $\mu \sigma \mathrm{\sigma} \varsigma)$ - vjerno oponašanje jednostavno prisutnog modela - i aletheia $(\dot{\alpha} \lambda \dot{\eta} \theta \varepsilon 1 \alpha)$ - svojevrsno samorazotkrivanje istine, "podizanje vela, razotkrivanje same stvari, onoga što jest utoliko što jest« (Derrida, 1972: 219), onda bismo mogli reći da je poetski jezik, kako ga zamišlja Mallarmé, napustio prvi modus, ali još nije, a nikad ni neće, doseći drugi. Jedino što preostaje riječima koje su se našle u tom međuprostoru jest onaj slavni centre de suspens vibratoire (Mallarmé, 1970: 386), a taj međuprostor, bjelina ili nabor, postaje drugi ritam, prostor vibracije riječi koje su uhvaćene, same, između dviju artikulacija istine.

Gotovo da nije potrebno pokazivati koliko je taj ritam vibracije raširen Mallarméovim opusom, dovoljno je sjetiti se ritmičnih pokreta krila, lepeze ili klatna sata i otkucaja srca u Igituru; možemo se također prisjetiti inkantacije »Literarne simfonije $\ll$ - »Moderna muzo Nemoći što mi odavno braniš poznatu riznicu Ritmova.« (Mallarmé, 1970: 261). Ritmovi su ovdje, s jedne

Napomenimo da za francuski glagol évoquer rječnik nudi više značenja, među ostalim: dozivati, prizivati, oživiti. 
strane, pisani velikim slovom, te bismo mogli reći da jednostavno označavaju umjetničko stvaranje; s druge se strane ne smije zanemariti uporabljenu množinu (trezor Ritmova, ne Ritma): kao da je to umjetničko stvaranje razapeto među svim navedenim ritmovima: onog stiha, forme, ideje, i onog drugog, ritma bjeline, tišine, tajne, vibrirajuće riječi koju je istina napustila.

Naglasak je, dakle, prebačen s fenomena na proces njegovog nastanka ili, držeći se terminologije koju smo uveli dajući pregled temeljnih Husserlovih postulata, s bitne strukture na njenu genezu. Sama geneza fenomena, njegovo postajanje, dolazak do prisutnosti - bilo jezika, bilo predmeta - mora se prezentirati kao fenomen. Ritam tako postaje preduvjet, temelj fenomena, te se sam očituje ne očitujući se, jedino u prazninama, kao totalni ritam bjeline; poetski tekst ne mora samo dovesti do prezencije eidosa jezika i predmeta, on sebi, kao nemoguć zadatak, zadaje prezentirati postajanje fenomena prezentnim: fenomenom mora postati postajanje fenomenom.

Oko tog drugog, izazovnijeg pola ritma gradit će se estetske teorije koje će odsad predstavljati temeljni predmet našeg interesa, ali će se isto tako pokazati da je presudno važno ne izgubiti dvostruku semantiku Mallarméova ritma iz vida, ako se želi doseći određenu tendenciju modernističke umjetnosti koju će ova analiza pokušati skicirati. Kao prva i temeljna točka analize te tendencije poslužit će nam paralelno prikazane Derridaove analize Hussserla i Mallarméa te ćemo pokušati pokazati kako on oba autora pronalazi isti paradoks: radikalno promišljanje prezencije forme - bilo estetsko, bilo fenomenološko - uvijek se u konačnici suočava s neprezentnim u svojemu temelju.

\section{Između Husserla i Mallarméa: Derrida i ritam pojavnosti}

Kako se Derridaova rasprava s Husserlom provlači kroz velik broj tekstova, a naš je prostor ograničen, morat ćemo se zadovoljiti time da skiciramo tek nekoliko ključnih kritičkih naglaska.

U početku je važno naglasiti da Derrida u potpunosti priznaje kritički stav što ga je Husserlova fenomenologija zauzela prema metafizičkom ili, Derridaovim vokabularom, ontoteološkom nasljeđu. Ipak, Husserl kao da se nije usudio do krajnjih konzekvenci slijediti vlastite premise te se u ključnim trenutcima ipak morao vratiti radikalno metafizičkim postulatima. Dva su temeljna Husserlova postulata sustavno izložena Derridaovoj kritici: s jedne strane, punktualni prezent čiji smo opis pokušali ponuditi, s druge strane, transcendentalno Ja koje se refleksivno odnosi samo prema sebi unutar čiste samoprisutnosti: »prezent ili prisutnost smisla u punoj i originarnoj intuiciji« (Derrida, 1976: 3).

Derrida, međutim, smatra da same Husserlove premise zapravo već urušavaju mogućnost originarne intuicije i prezenta. Dekonstrukciju prezenta već smo donekle skicirali: prezent se uvijek pojavljuje kao fenomen tek razlikujući se od retencija i protencija, noseći na sebi njihov trag; pročitajmo još jednom pažljivo Husserla:

»Forma dobiva uvijek novi sadržaj, dakle, svakoj se impresiji, u kojoj je dan doživljaj Sada, 'priključuje' neka nova impresija koja odgovara nekoj kontinuirano novoj točki trajanja; impresija se kontinuirano pretvara u retenciju, a ta se retencija kontinuirano pretvara u modificiranu retenciju itd.« (Husserl, 2007: 191)

Naizgled se ovdje radi o jednostavnom toku prezentnih trenutaka koji, čim prođu, postaju retencije; Derrida, međutim, uočava da se svakom Sada kao 
Sada već priključuje novo Sada - potencija - te se to Sada kontinuirano pretvara u retenciju: sada u svojoj strukturi već nosi nužnost toga da će postati retencija te da će biti smijenjeno protencijom; identitet Sada ovisi o čistom tragu retencije i protencije koji se u njega upisuje:

»Živi se prezent ne konstituira kao apsolutan izvor percepcije osim u kontinuitetu s retencijom kao ne-percepcijom.« (Derrida, 1976: 75)

Prezent se konstituira unutar onoga što Derrida, pomalo metaforički, naziva »treptajem«; prezentni trenutak percepcije ovisi o igri tragova bilo koje retencije ili protencije, o igri traga po sebi:

$» .$. trag u najuniverzalnijem smislu, jest mogućnost koja ne mora samo nastanjivati čistu aktualnost sadašnjosti, nego je i konstituira samim pokretom différance što je u sadašnjost uvodi.« (Derrida, 1976: 75)

Pritom nije nevažno obratiti pažnju na francuski termin clin d'œil što ga Derrida upotrebljava: on, s jedne strane, označava trenutak, mogli bismo ga prevesti s »tren oka«, s druge strane, doslovno, on pretpostavlja zatvaranje oka, prekid percepcije. U toj je dvoznačnosti zapravo sadržan paradoks fenomenologijskog vremena za Derridaa: trenutak nastaje tek na osnovu traga, ne-percepcije, neuhvatljivog treptaja koji se nikad ne pojavljuje kao fenomen.

To bi otprilike bio smisao prelaska s onu stranu fenomenologije: nakon eidetske redukcije, nakon što je svijet stavljen u zagrade, pojavit će se čisti fenomeni, ali će opća forma - prezent - unutar koje se pojavljuju te forme u sebi već nositi trag nepojavnog, différance. Treba, međutim, uzeti u obzir to da se différance pojavljuje tek kroz ogromni napor fenomenologijskog istraživanja: ako Husserlova filozofija nju ne može integrirati, to ne znači da se tu filozofiju može odbaciti; transcendentalna je fenomenologija nužna kako bi se pojavilo ono što nikada ne postaje fenomenom.

Sličnu interpretaciju Derrida nudi i kada je u pitanju transcendentalni subjekt: taj je subjekt, prema Derridaovu tumačenju, mišljen kao čista autoafekcija glasom. Glas bi trebao čuvati čistu samoprisutnost, sažeti je u jedan jedini trenutak onog poznatog »čuti se govoriti«, s'entendre parler: dok se tihim glasom obraća sebi, subjekt već čuje samoga sebe, unutar momenta glasa nema opasnosti od odgode ili eksteriorizacije koja se pojavljuje s pismom. Pa ipak, Derrida naglašava, čim se pojavi autoafekcija - gotovo bismo mogli reći razlika između ja po sebi i ja za sebe - svaka čista samoprisutnost postaje nemoguća:

»Čim priznamo da je autoafekcija uvjet prisutnosti sebi, nikakva čista transcendentalna redukcija nije moguća. [...] Taj pokret différance ne događa se slučajno transcendentalnom subjektu. On ga stvara. Autoafekcija nije modalitet iskustva karakterističan za biće koje već jest ono samo (autos). Ona proizvodi isto kao odnos sa sobom unutar razlike prema sebi, isto kao neidentično.« (Derrida, 1976: 92)

Koliko god glas trebao jamčiti da će se pošiljatelj i primatelj savršeno poklopiti unutar trenutka, on uvijek među njih uvodi razliku: Derrida, stoga, piše da biti »za sebe« (pour soi) uvijek već znači biti »umjesto sebe« (à-la-place-desoi; usp. Derrida, 1976: 99). I opet, ne možemo zato jednostavno zanemariti fenomenologijska istraživanja; nastavimo prethodni citat:

»Čim priznamo da je autoafekcija uvjet prisutnosti sebi, nikakva čista transcendentalna redukcija nije moguća. Ali moramo njome proći kako bismo uhvatili razliku kad je najbliža samoj sebi: ne njen identitet, ni njenu čistoću, ni njen izvor. Jer njih nema. Nego pokret différance.« (Derrida, 1976: 92; kosopis A. P.) 
Zapravo se čitav Derridaov rad na Husserlovoj fenomenologiji očituje unutar tog prolaska transcendentalnom redukcijom: tek kad se pojave čisti fenomeni, čiste forme, eidos predmeta, iza njih se može nazrijeti ritam razlike i traga, onoga što se nikad ne pojavljuje:

»... trag koji se po sebi nikad ne može prezentirati: pojaviti se i manifestirati kao takav unutar svog fenomena.« (Derrida, 1975: 23-24)

Ako, međutim, fenomenologija gotovo protiv same sebe dolazi to te granice, književni tekst, Mallarméov tekst, svojevoljno sebi zadaje takvu putanju: od savršene, čiste forme prijeći do nemanifestnog, gotovo na silu natjerati ono neprikazivo da izađe iz svog skrovišta. Pokušajmo sada proći njegovom putanjom.

Derrida u svojoj analizi Mallarméa temeljni naglasak stavlja na pitanje mimesisa; on, analizirajući »Mimique«, virtuozno ukazuje na različite mehanizme koji - od razine intertekstualnosti do razina sintakse i semantike - urušavaju klasičnu strukturu mimesisa u Mallarméovu tekstu te dolazi do zaključka da Mallarmé ne pokušava jednostavno napustiti reprezentaciju, prijeći s onu stranu prikazivanja, nego »zadržava diferencijalnu strukturu pantomime ili mimesisa, ali bez platonističke ili metafizičke interpretacije koja implicira da je oponašano biće nekog bivstvujućeg «(Derrida, 1972: 234). Za Derridaa se, dakle, radi o samoj mimesis, takoreći oponašanju bez oponašanog i oponašatelja. Takvoj bi se interpretaciji, međutim, moglo predbaciti da je daleko tradicionalnije filozofska, nego što se predstavlja, štoviše, da sam Mallarméov tekst predstavlja daleko više metafizičkim, nego što on to jest. Derrida kao da izvodi onu klasičnu gestu koju je toliko puta napadao i traži mimesis, oponašanje po sebi, odvojeno od svakog modela i kopije, mogli bismo reći formu, eidos oponašanja. Time se još jednom krećemo na planu prezentacije: Mallarméov tekst ne nudi nam samo eidos jezika i eidos predmeta, on, krajnje naprežući odnose predstavljanja, do prisutnosti dovodi i ono što ih povezuje: mimesis kao prezentaciju reprezentacije.

Treba, međutim, uzeti u obzir da je oponašanje po sebi diferencijalna struktura, da se odvija između prikaza i prikazanog, kao što se ritam odvija u razmacima otkucaja, prezent u razmacima treptaja, a čisto Ja u razmacima autoafekcije. Mimesis nije pozitivan entitet; ne može prikazati gestu prikazivanja po sebi, prikazivanje koje ništa ne prikazuje. Potraga za čistom mimesis tako postaje potraga za elementom koji otvara prostor teksta, ali ga u tekstu, strogo uzevši, nema:

»Neprekidno se obrćući oko svog vrška, hijeroglif, znak, šifra, napušta svoje ovdje, kao da se zabija, uvijek ovdje i prelazeći onamo, od jednog do drugog ovdje, upisujući u stigmu svog ovdje drugi vršak prema kojem se kontinuirano prenosi, drugu piruetu koja se u svakom obratu, u letu svakog tkanja trenutno ponovno označava.« (Derrida, 1972: 272)

To ponovno označavanje (remarque), »znak operacije označavanja« (usp. Derrida, 1972: 274), »prostor pisanja« (Derrida, 1972: 284), »bjelina koja dopušta znak « (Derrida, 1972: 285), to »više ili manje teme « (Derrida, 1972: 284) ostaje »nepoželjivo« (indésirable) i neopisivo (Derrida, 1972: 284). Mogli bismo reći da mimesis po sebi kronološki i logički prethodi tekstu, ali da ga tekst, uvijek već premrežen logikom označitelja, označenog i referenta, nikada ne može obuhvatiti. Tako Mallarméov mimesis donekle zauzima mjesto drugog ritma i différance izvedene iz Husserlove potrage za fenomenom. 
Ovakva bi paralela, međutim, ostala prilično slaba ako se ritam ne bi pojavio i u Derridaovoj analizi. Vratimo se, stoga, uvodu Derridaova izlaganja. Ondje čitamo:

»To što uništava 'bogobojazno veliko slovo' naslova, radi na dekapitaciji teksta, to je redovita intervencija bjeline, mjera i poredak diseminacije, zakon oprostorenja, $\dot{\rho} \check{v} \theta \mu o ́ \varsigma$ (kadenca i karakter pisma).«(Derrida, 1972: 204)

$P \breve{v} \theta \mu o ́ \varsigma$, ritam bjeline, vršak hijeroglifa, neizreciv i nepoželjiv, u Derridaa tako zauzima onu poziciju koju smo pokušali izlučiti paralelno čitajući niz Mallarméovih tekstova. Uz to nam Derrida nudi i zanimljivu bilješku, referencu na knjigu Problèmes de linguistique générale Émila Benvenista, a u toj ćemo studiji pronaći kratko poglavlje o riječi ritam koje će dodatno rasvijetliti skiciranu problematiku.

Benveniste zapravo nudi jednostavnu bilješku o etimologiji riječi ritam. Ritam, prema tradicionalnom shvaćanju, dolazi od grčkog glagola $\dot{\rho} \varepsilon i ́ \omega-t e c ́ i$. Kako je taj glagol povezan s pokretom vode, od njega se prelazi prema pravilnom pokretu morskih valova te je moguće donijeti sljedeći zaključak: promatrajući ritam valova, antički ga je Grk povezao s glagolom ṕeí i tako je nastao ṕv̆$\theta \mu$ ó (usp. Benveniste, 1966: 327).

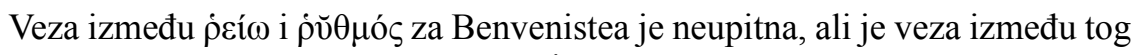
glagola i valova potpuno neodrživa: $\dot{\rho} \varepsilon i \omega$ se nikada ne upotrebljava vezan uz more, on označava tok vode, primjerice rijeke, a »voda tekućica nema ritma«

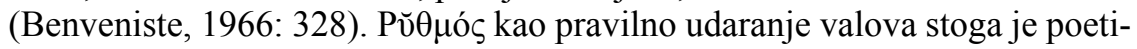
zirana, fikcionalna, neodrživa etimologija. Benveniste se zatim pita u kojem

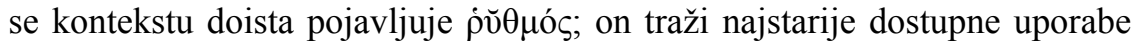

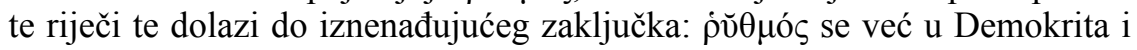
Leukipa pojavljuje kao tehnički termin te je istoznačan izrazu shema, forma:

»Nema nijedne varijacije, nikakve dvoznačnosti u značenju koje Demokrit pripisuje $\rho \breve{v} \theta \mu o ́ c u$ koji je uvijek 'forma', pri čemu se misli na distinktivnu formu, karakteristično uređenje elemenata unutar cjeline.« (Benveniste, 1966: 330)

U Platona, a zatim i Aristotela, ta će uporaba biti zadržana te će se značenje riječi $\rho \breve{v} \theta \mu o ́ \varsigma$ približiti značenju rasporeda, figure uređenih proporcija (usp. Benveniste, 1966: 330).

Benveniste, međutim, naglašava da u starogrčkom postoji više izraza koji bi približno označavali formu - shema, morphe, eidos - od kojih se, barem u nijansi, $\dot{\rho} \breve{v} \theta \mu$ ó $̧$ razlikuje. A do te se nijanse može doprijeti uzme li se u obzir dva elementa: s jedne strane, poveznicu s glagolom $\dot{\rho} \varepsilon i ́ \omega$, s druge strane, sufiks -mos koji, povezan s apstraktnim izrazima, upućuje na određenu nezavršenost (usp. Benveniste, 1966: 332); $\rho \breve{v} \theta \mu$ ó tako pronalazi svoju specifičnost:

»... on označava formu u trenutku u kojem je preuzima ono što je pokretno, mobilno, fluidno, to je forma onoga što nema organske konzistencije [...]. To je improvizirana forma, trenutačna, promjenjiva.« (Benveniste, 1966: 333)

P $\breve{\theta} \theta \mu$ ó, , »specifičan način na koji se teče « (Benveniste, 1966: 333), u svojoj je prvoj uporabi artikulacijski moment koji omogućava materiji postojanje, moment koji, formirajući provizorne kombinacije među atomima, dovodi stvari do prisutnosti (usp. Benveniste, 1966: 333).

Zapravo se čitava problematika koju smo pokušavali pratiti kretala oko ova dva pola riječi ritam: ritam je forma u smislu figure uređenih proporcija, ali je ritam istovremeno forma u smislu temeljnog, negativnog principa artikulacije, principa koji dovodi do pojavnosti. Ako se fenomenologija, gotovo 
protiv vlastite volje, u trenutku kada se činilo da fenomen blista u vlastitoj prisutnosti, morala suočiti s tim nefenomenalnim principom, Mallarméov je tekst svojevoljno činio prijelaz od ritma pojave jezika i predmeta kao eidosa do ritma bjeline.

Čvrstu vezu između ritma i (ne)pojavnosti, vezu koja nas vraća Derridaovu radu na Husserlovoj fenomenologiji, nudi Jean-Luc Nancy naglašavajući da se ritam »ne 'pojavljuje'; on je otkucaj pojavnosti utoliko ukoliko se ona istodobno i neraskidivo sastoji u dolaženju i odlaženju oblika ili prisutnosti općenito« (Nancy, 2014: 48). Nalazimo se na poznatom terenu: ritam je ponovno koncipiran kao formativni princip forme i prisutnosti; Nancy, međutim, također naglašava da ritam, taj formativni princip, »ima vlastiti moment jedino u razmaku otkucaja koji ga čine ritmom« (Nancy, 2014: 48; kosopis A. P.). Zapravo bismo iz te perspektive mogli reći da se i sam ritam uvijek razlikuje od sebe: on nije ni u naglasku ni u odsutnosti naglaska, ritam ritmom čini isključivo njihova pravilna izmjena, očekivanje naglaska u trenutku tišine ili očekivanje njegovog nedostatka u trenutku naglaska. Ako je ritam prvenstveno vremenski fenomen, onda je takav vremenski fenomen unutar kakvoga doista »ne postoji prezent« (Mallarmé, 1970: 372), čista igra protencije i retencije unutar koje je prezentni trenutak bezvrijedan. Ritam je najradikalniji oblik Derridaova traga (trace), ne samo da kontaminira identitet svakog označitelja uvodeći u njega razliku, ili samu mogućnost razlike prema drugim označiteljima, nego ritmom i kao da je kontaminirana materijalnost, vrijeme, oni morski valovi po kojima je, prema pogrešnoj etimologiji, dobio ime; princip prisutnosti i forme, ousia i eidos, otkucaj pojavnosti nalazi se jedino u razmaku otkucaja, bjelini stranice koja je i sama svinuta.

Ritam je tako postao svojevrsno mjesto susreta Mallarméova poetskog rada i Husserlove fenomenologije, on je onaj princip do kojeg se dolazi kada se teoriju prezentacije napregne do krajnjih granica. Naravno, potrebno je još jednom podsjetiti na razliku između ta dva diskursa: dok fenomenologija pokušava potisnuti princip fenomenalnosti i sačuvati sam fenomen, Mallarméov tekst, kako na formalnoj, tako i na sadržajnoj razini, pokušava izvesti svojevrsnu kontaminaciju, ne dozvoliti fenomenu (savršenom jeziku koji svoj predmet dovodi do prisutnosti) da se odvoji od razlikovnog principa koji ga stvara: ritam-formu mora se napregnuti do te mjere da se kroz nju nazre ritam-otkucaj pojavnosti. Ako je Derrida tvrdio da se tek prolaskom kroz fenomenološku redukciju différance može uhvatiti kada je najbliže sebi, Mallarméov program postulira da se tek prolaskom kroz ritam savršenog jezika i savršene forme može približiti ritmu bjelina.

\section{Odjeci Mallarméova ritma}

Da bismo pokazali koliko je važan i rasprostranjen postao ovaj estetski program koji od umjetničkog djela traži da prokrči put ne samo fenomenu nego i ritmu koji se iza njega krije, skicom ćemo prikazati teorije ritma troje velikih suvremenih filozofa.

Radeći upravo na Mallarméovim tekstovima, Julia Kristeva dolazi do zaključka da oni izražavaju »ritam nesvjestan, nagonski, translingvistički, upisan u nacionalni jezik, ali koji cilja, preko njega, neku drugu scenu« (Kristeva, 1974: 212). Taj ritam, ritam kore teži »probiti ono što je za subjekt znak i rekonstruirati heterogen prostor njegovog stvaranja« (Kristeva, 1974: 95); »razderati veo reprezentacije kako bi se pronašlo materijalni proces označa- 
vanja« (Kristeva, 1974: 98). Potrebno je međutim, naglasiti da drugi ritam ni za Kristevu ne upućuje na jednostavnu materijalnost iza znaka: druga scena, kora, prostor je unutar kojeg se nagoni upisuju u »materijale pogodne za semiotizaciju - glas, geste, boje« (Kristeva, 1974: 28), prostor u kojem materijali prolaze kroz svojevrsnu prvu, nagonsku artikulaciju. Ritam je, dakle, još jednom postao negativan artikulacijski princip koji omogućuje da se za »tetički subjekt« (Kristeva izraz, naravno, izvodi iz Husserla) svijet pojavi kao fenomen, kao »forma onoga što nema organske konzistencije«, a taj se ritam izražava ne izražavajući se, prvenstveno u poetskom tekstu.

Giorgio Agamben u predzadnjem poglavlju studije Čovjek bez osobina analizira citat iz druge ruke; on navodi kako je Bettina von Arnim u svoju knjigu Die Günderoden uključila Hölderlinovu rečenicu koja potječe iz razdoblja pjesnikove mentalne bolesti; citat, dakle, iz treće ruke:

»Sve je ritam, čitava ljudska sudbina jedan je božanski ritam, baš kao što je svako umjetničko djelo jedan ritam, a sve se njiše s poetizirajućih usana boga.« (Hölderlin, cit. prema Arnim, prema Agamben, 1999: 94)

Agamben će se odmah zapitati što bi označavao taj božanski ritam. Prvo rješenje koje on nudi, oslanjajući se na Aristotela, jest to da je ritam za Hölderlina strukturirajući princip, element ili sila koja bezobličnom daje oblik:

»U tom smislu ritam je struktura, shema, u opreci prema elementarnoj, neartikuliranoj prirodi.« (Agamben, 1999: 95)

Agamben, međutim, oslanjajući se i dalje na Aristotela, odmah zatim upozorava na temeljni paradoks svake strukture: ako je ona više od zbroja svojih dijelova, struktura ne može obuhvatiti vlastiti princip, to »više«, onaj višak koji je čini strukturom (usp. Agamben, 1999: 95). Krećemo se, dakle, unutar problematike slične onoj koju je Derrida skicirao u antologijskom eseju »Struktura, znak i igra u diskursu humanističkih znanosti«: premda je struktura definirana isključivo kao skup odnosa među elementima, uvijek se postavlja potreba za time da se uspostavi određeno transcendentalno označeno, element koje će upravljati njenom igrom, koji će nositi pozitivan identitet te joj time nikad neće u potpunosti pripadati (usp. Derrida, 1967: 409-410).

Agamben, međutim, neće tražiti jedan element strukture koji upravlja svima ostalima, on će kao zasebnu snagu izdvojiti aristotelijansku ousiu (ov̉бía), »princip koji daje podrijetlo i sve zadržava u prisutnosti« (Agamben, 1999: 97), ousiu kao svojevrstan prazni princip strukturiranja strukture, kao njen višak. Ousia zato »nije materijalan element nego Forma ( (Agamben, 1999: 97).

Forma je tako izgubila statičnost, ona sama niti je Ideja, niti uređen skup odnosa, nego »temeljni princip prisutnosti, $\dot{\rho} \breve{v} \theta \mu o ́ s$, struktura shvaćena kao sinonim Formi« (Agamben, 1999: 97). Idući korak dalje, Agamben zatim, unutar iznimno guste argumentacije, navodi kako bi se »bez očitog nasilja $\dot{\varepsilon} \pi o \chi \eta ́$ moglo prevesti kao ritam« (Agamben, 1999: 97). Epohé, međutim, ta-

Napomenimo da je Agamben, kao dobar poznavatelj opusa Mauricea Blanchota, mogao pronaći ovaj citat te njegovu analizu i u knjizi L'Entretien infini. Blanchot povodom tog citata piše: »U tom obratu koji je ritam riječ se okreće prema onome što skreće i što se preobrće. To je rijetka riječ: ne poznaje užurbanost, kao odbijanje da se ode dalje ili sumnju koja titra jednoliko. Najiskrenija je u svojoj poprečnosti, uvijek ustrajući u upadici, uvijek pozivajući na stranputicu te nas tako držeći u napetosti između vidljivog i nevidljivog ili onkraj jednog i drugog.« (Blanchot, 1977: 43) 
kođer gubi svoj huserlijanski smisao eidetske redukcije koja vodi do ideje ili biti predmeta:

»Ali glagol $\varepsilon \pi \varepsilon \chi \omega$ ima treće značenje u Grčkom [...]: biti, u smislu 'biti prisutan, biti ondje, dominirati, držati’.« (Agamben, 1999: 97)

Epohé je, dakle, kao i Forma, postala princip prisutnosti; ne radi se više o čuđenju, o objektivnoj percepciji biti, nego o procesu samog njenog nastanka, "pro-dukciji u prisutnost«.

Ovi su semantički pomaci od presudne važnosti. Agamben eksplicitno izjednačava sve elemente serije ritam - forma - epohé te im, jednim potezom, izmiješta značenje: od nepromjenjivih biti, modela za postojeće predmete, oni postaju djelatan princip, princip prve artikulacije:

»To da je umjetnost arhitektonična znači, etimološki: umjetnost, poiesis, jest pro-dukcija ( $\tau i ́ \kappa \omega)$ temelja ( $\dot{\alpha} \rho \chi \eta ́)$, umjetnost je dar originalnog ljudskog prostora, arhitektura par exellence.« (Agamben, 1999: 97)

Upravo bi se iz te hölderlinovsko-agambenovske perspektive moglo čitati Mallarméov drugi ritam, ritam invokacije koji dovodi do prisutnosti cvijet odsutan iz svih buketa: ni kao ritam duše, ni kao ritam riječi, ni kao ritam esencijalne i nepromjenjive forme-modela: ni prisutnost same ideje-cvijeta, ni njen vjeran odraz u riječima, ni mimesis, ni aletheia. Umjesto toga, ritam se pojavljuje kao bjelina, nabor, apsolutni, ali tihi princip, eidos-ousia, koji otvara prostor duše, stiha i forme, ali im istovremeno izmiče. Potraga za tim ritmičnim principom bila bi, pak, gotovo opsesija nekih struja postmoderne estetike.

Pogledajmo kako taj sklop funkcionira kod Jacquesa Rancièrea. On polazi od sljedeće pretpostavke: prije svega, Mallarmé svjedoči krizi, ne stiha, nego forme općenito. U doba »prirode i njene reprezentacije« (Rancière, 1996: 29) ili, ako hoćemo, poetskog režima, postoje dvije temeljne vrste modela: likovi čije iskustvo nalikuje našem te likovi koji predstavljaju arhetipove hrabrosti, ljepote, dužnosti itd. (usp. Rancière, 1996: 30). Čak i ti arhetipovi, međutim, imaju svoje modele:

»... ideju ili formu, platonovski eidos koji je svoj ljudskoj stvarnosti - pravdi grada ili stolarovom krevetu, ljepoti ili úšī - nudio božanski model što ga je ona nesavršeno pokušavala oponašati.« (Rancière, 1996: 30)

Problem je $u$ tome što su te forme, temelj svake reprezentacije, upale $u$ krizu:

»Anegdotalna kriza poštovanog aleksandrinca upućuje na puno ozbiljniji nestanak neba Ideja.« (Rancière, 1996: 30)

Kada se, međutim, izgubi transcendentalni temelj mimesisa, »samo dijalektika stiha može izbrusiti pečat ideje, grupirajući prema esencijalnom ritmu, 'sve pravce, razbacane, zanemarene, plutajuće' " (Rancière, 1996: 30; kosopis A. P.). Nije teško primijetiti da je ritam i ovdje postao element koji dovodi eidos do prisutnosti, ritam stvara »prekarni idealitet« (Rancière, 1996: 30). Kad emblem pjesme postane lepeza, njen dvostruki ritam rastvaranja i otvaranja te mahanja, tad pjesma više ništa ne govori, nego »emblematizira gestu govora kao skandiranje pojavljivanja i nestajanja« (Rancière, 1996: 50). Još jednom, pjesma mora uputiti na trenutak vlastite artikulacije, ritam koji brusi pečat ideje, koji kronološki i logički prethodi samom tekstu te mu ne pripada:

»Modus u kojem se misao izražava kao ritam prethodi svom diskurzivnom modusu te mu je superioran: on ne označava rezultat misli nego sam pokret njenog uzleta.« (Rancière, 1996: 90) 
Radi se, dakle, o nemogućoj inkorporaciji principa koji stvara Ideju-Formu, ali joj ne pripada. Pjesma, premda autoreferencijalna - emblem same sebe kao da se istovremeno sustavno promašuje. A u tom razmaku, razmaku između Ritma-Forme i Ideje-Forme, otvara se, još jednom, možda posljednji put, »ritual posvećenja ljudskog boravišta« (Rancière, 1996: 39).

\section{Zaključak}

Pokušali smo demonstrirati kako se oko pojma ritma, definiranog već kod Mallarméa na dvije razine - ritma forme i ritma-postajanja formom, prelama određena suvremena estetska debata $\mathrm{s}$ fenomenološkim postulatima. Pritom je važno naglasiti da teorija prezentacije fenomena kod navedenih filozofa nije napuštena; njen je naglasak promijenjen: od umjetničkog se djela ne traži samo to da dovede fenomen do prisutnosti te da postigne formalno savršenstvo (prvi ritam) nego se od njega, prvenstveno, zahtjeva i da do prisutnosti dovede dolazak fenomena (drugi ritam). Kako, međutim, stvarnost prolazi kroz isti proces - artikulira je ritam kore, ritam ousie, ritam misli - ova estetika, utemeljena prvenstveno na visokom modernističkom nasljeđu, nikako ne postulira larpurlartizam: drugi ritam postaje scena susreta umjetnosti i stvarnog; umjetničko djelo, krajnjim naporom dosežući savršenu formu, pokušava izvesti na vidjelo nefenomenalan princip koji stvarnosti omogućuje da se pojavi kao fenomen. Ono stoga doista kao da dubi prostor ritma, jedini prostor unutar kojeg se može smjestiti »ljudsko boravište«, »originarni ljudski prostor«.

\section{Literatura}

Agamben, Giorgio (1999): The Man Without Content, prev. Georgia Albert, Stanford University Press, Stanford.

Baudelaire, Charles (1976): Euvres complètes, sv. 2, Claude Pikhois (ur.), Éditions Gallimard, Pariz.

Benveniste, Émile (1966): Problèmes de linguistique générale, Éditions Gallimard, Pariz. Blanchot, Maurice (1977): L'Entretien infini, Gallimard, Pariz.

Chassé, Charles (1954): Les clefs de Mallarmé, Aubier - Éditions Montaigne, Pariz.

Derrida, Jacques (1967): L'écriture et la différence, Éditions de Seuil, Pariz.

Derrida, Jacques (1972): La dissémination, Éditions du Seuil, Pariz.

Derrida, Jacques (1975): Marges de la philosophie, Les Éditions de Minuit, Pariz.

Derrida, Jacques (1976): La voix et le phénomène. Introduction au problème du signe dans la phénoménologie de Husserl, Presses Universitaires de France, Pariz.

Evans, David (2004): Rhythm, Illusion and the Poetic Idea. Baudelaire, Rimbaud, Mallarme, Rodopi, New York - Amsterdam.

Genette, Gerard (1976): Mimologiques. Voyages en Cratylie, Éditions du Seuil, Pariz.

Husserl, Edmund (2007): Ideje za čistu fenomenologiju i fenomenologijsku filozofiju, prev. Željko Pavić, Naklada Breza, Zagreb.

Kidder, Paul (1987): »Husserl's Paradox«, Research in Phenomenology 17 (1987) 1, str. 227-242, doi: https://doi.org/10.1163/156916487x00120.

Kristeva, Julia (1974): La révolution du langage poétique. L'avant-garde à la fin du XIXe siècle, Lautréamont et Mallarmé, Éditions du Seuil, Pariz. 
Lloyd, Rosemary (2000): »Mallarmé at the Millenium«, The Modern Language Review 95 (2000) 3, str. 674-683, doi: https://doi.org/10.2307/3735495.

Mallarmé, Stéphane (1970): Euvres complètes, Henri Mondor - G. Jean-Aubry (ur.), Éditions Gallimard, Pariz.

Marx, Werner (2004): Fenomenologija Edmunda Husserla. Uvod, prev. Božo Dujmović, Naklada Breza, Zagreb.

Nancy, Jean-Luc (2014): Muze, prev. Vanda Mikšić, Meandarmedia, Zagreb.

Ouellet, Pierre (1989): »L'idée d'Idée: une eidétique mallarméenne«, Études littéraires 22 (1989) 1, str. 11-26, doi: https://doi.org/10.7202/500884ar.

Rancière, Jacques (1996): Mallarmé: la politique de la sirène, Hachette Littératures, Pariz. Schopenhauer, Arthur (2012): O geniju. Eseji, prev. Marija Škorić, CID-Nova, Zagreb.

\title{
Adrian Pelc
}

\section{Mallarmé's Rhythm: Between Phenomenon and Différance}

\begin{abstract}
The notion of rhythm in the works of Stephane Mallarmé has a specific position upon which all the poet's most taunting ideas refract. Following the line this notion opens, in the first step established are the parallels between Mallarmé's aesthetic postulates and Husserl's phenomenology. In the second step, the Husserl-Mallarmé parallel serves as a matrix for understanding some basic paradoxes of Derrida's deconstruction. It will be shown that Derrida, too, was in search of a specific, distinctive rhythm. In the third step, it will be shown how from Mallarmé, over Derrida's workthrough, the rhythm (rhythm of appearance and rhythm of verse, rhythm of words and rhythm of whiteness) became one of the discrete, but most radical theoretical premises among some of the most influential philosophers of the postmodern: Agamben, Kristeva, Rancière, Nancy.
\end{abstract}

\section{Keywords}

Stephane Mallarmé, Jacques Derrida, Edmund Husserl, verse, rhythm, deconstruction, phenomenon, idea 